\title{
CHANGES IN SOIL STRUCTURE AND SOIL ORGANIC MATTER DUE TO DIFFERENT SEVERITIES OF FIRE
}

\author{
VLADIMÍR ŠIMANSKÝ
}

Department of Soil Science, Faculty of Agrobiology and Food Resources, Slovak University of Agriculture, Tr. A. Hlinku 2, 94976 Nitra, Slovak Republic; e-mail: Vladimir.Simansky@uniag.sk

\begin{abstract}
Šimanský V.: Changes in soil structure and soil organic matter due to different severities of fire. Ekológia (Bratislava), Vol. 34, No. 3, p. 226-234, 2015.

The effect of different fire severity on the changes of the soil organic matter (SOM) and soil structure was evaluated. Soil samples were collected (May 2010) in the locality of Nitra-Dražovce (Slovakia) from the following plots: 1) control (unburned place), 2) low severity of fire and 3) higher severity of fire. The results showed that the content of water-stable microaggregates ( $\mathrm{WSA}_{\mathrm{mi}}$ ) increased by $20 \%$ in the area with a low severity of fire, but on the other hand, it decreased by $42 \%$ in the area with the higher severity of fire in comparison to control. The higher severity of fire resulted in a decrease of smaller size fractions of water-stable macroaggregates (WSA $\left.{ }_{\mathrm{ma}}\right)(0.5-0.25)$ and a low severity of fire resulted in the decrease of WSA $2-0.5 \mathrm{~mm}$. On the other hand, the content of WSA $_{\text {ma }}$ in the size fraction $>5 \mathrm{~mm}$ was higher by $54 \%$ and by $32 \%$ in the lower and higher severity of fire, respectively, than in unburned soil. The higher severity of fire had a more positive effect on increases of the structure coefficient and coefficient of aggregate stability, as well as on the decrease of the vulnerability coefficient compared to the low severity of fire. After burning, the contents of soil organic carbon $\left(\mathrm{C}_{\text {org }}\right)$ and labile carbon were significantly increased by the severity of fire. However, the low severity of fire affected more markedly the increase of hot water-soluble and cold water-soluble carbon than the higher severity of fire. After burning and due to the severity of fire, both the carbon of humic and carbon of fulvic acids ratios and SOM stability increased. The parameters of SOM due to fire significantly increased also in WSA with the least changes in WSA $_{\text {mi: }}$. The results showed that a low severity of fire increased $\mathrm{C}_{\text {org }}$ mainly in WSA $\mathrm{ma}_{\mathrm{ma}}>2 \mathrm{~mm}$ and $\mathrm{WSA}_{\mathrm{mi}}$, whereas high severity fire increased $\mathrm{C}_{\text {org }}$ content in the smaller fraction of WSA ${ }_{\mathrm{ma}}$.
\end{abstract}

Key words: size fraction of water-stable aggregates, soil organic carbon, labile carbon, fire.

\section{Introduction}

Slovakia is not a country where wildfires cause major damage compared with the Mediterranean regions, which are characterized by long, dry, hot summers and short, wet, mild winters (Hötzl, 2008). In recent years in Slovakia, however, due to increasing temperatures during the summer, an enhanced risk of a rapid spread of fires is evident. In this region, it is typical that the emergence of fires is due to burning of dry grass especially in spring, or the incineration of waste in the gardens. In summer, the risk increases due to ripening cereals and damage caused on the agricultural land. 
Fire can change importantly soil physical and chemical properties (Soto et al., 1991; Zavala et al., 2010; Mataix-Solera et al., 2011; Šimanský et al., 2012). In soil, physical properties such as the water repellency (Aelamanesh et al., 2014) and water-stable aggregates (Jordán et al., 2011; Šimanský et al., 2012) are considerably altered. The fire can increase or decrease the soil aggregate stability. This depends on factors such as burning temperature, time of burning, soil type, type of clay minerals, type of vegetation, the formation of hydrophobic substances during fire and the severity of fire (Garcia-Oliva et al., 1999; Mataix-Solera et al., 2011). Soil structure is often affected during the high severity of fire, whereas the low severity burning has often been thought to have a low or neutral effect on soil aggregation (Urbanek, 2013). For example, Albalasmeh et al. (2013) reported a mechanism of aggregate disruption during the fire. During rapid heating of moist soil aggregates, intra-aggregate water is vapourized and the increased pressure causes a rupture of the internal bonds and leads to aggregate breakdown. Soto et al. (1991) suggested that soil organic matter (SOM) consumption is a key element in aggregate stability after fire. Arcenegui et al. (2008) showed that the fire can increase aggregate stability. The results of Šimanský et al. (2012) showed that the soil affected by fire had the highest content of soil organic carbon, labile carbon and stability of aggregates, while the content of organic carbon in water-stable aggregates (WSA) was almost threefold in $\mathrm{WSA}_{\mathrm{mi}}$ (micro) than in $\mathrm{WSA}_{\mathrm{ma}}$ (macro). The relationship between soil structure and SOM is very obvious, since SOM is one of the most significant components controlling aggregate stability (Šimanský, Bajčan, 2014).

The aim of this work is to study the effects of low and higher severity of fire on the changes of the SOM and soil structure. We looked at the soil structure and SOM in a Rendzic Leptosol subjected to both low and higher severity of fire.

\section{Materials and methods}

\section{Site characteristics}

The study was carried out in the Dražovce locality $\left(48^{\circ} 21^{\prime} 6.16^{\prime \prime} \mathrm{N} ; 18^{\circ} 3^{\prime} 37.33^{\prime \prime} \mathrm{E}\right)$ near Nitra city in the western part of Slovakia. Dražovce is located under the western side of the Tribeč Mountain. The area of the Tribeč is divided into the Zobor and Tribeč parts of mountain area. Soil sampling was taken in the western foothill of the Zobor hill. There are vineyards on the southwest side of the Tribeč mountain. In the 11th century, the southern slopes of the Zobor hills were deforested and vineyards were planted. Today, the locality is used as a horticulture area and for growing plants to produce wines. The soil surface is covered with grass and weeds, but dominating are Rosa shrubs. The geologic substrate of the studied areas is mainly composed of a series of Mesozoic sedimentary rocks with a predominance of Cretaceous, Jurassic and Triassic limestones. The dominant soils are classified as Rendzic Leptosols (WRB, 2006) with the content of rock fragments more than $8 \%$ in the top $30 \mathrm{~cm}$, and with organic carbon $17.0 \pm 1.6 \mathrm{~g}$ $\mathrm{kg}^{-1}$, total nitrogen $1867 \pm 103 \mathrm{mg} \mathrm{kg}^{-1}$, base saturation percentage $99.3 \pm 0.01 \%$, $\mathrm{pH} 7.18 \pm 0.08$ in soil; the particle-size distribution is $569 \mathrm{~g} \mathrm{~kg}^{-1}$ of sand, $330 \mathrm{~g} \mathrm{~kg}^{-1}$ of silt and $101 \mathrm{~g} \mathrm{~kg}^{-1}$ of clay (Šimanský, 2013; Šimanský et al., 2013). The average temperature is $\geq 10{ }^{\circ} \mathrm{C}$ and the annual precipitation is $550 \mathrm{~mm}$ based on the data collected at the meteorological station of Dolná Malanta (lat. $48^{\circ} 19^{\prime} 00^{\prime \prime} \mathrm{N}$; lon. $18^{\circ} 09^{\prime} 00^{\prime \prime} \mathrm{E}$ ).

\section{Sample procedures}

In 2010, the burning of dry vine branches led to the outbreak of an uncontrolled fire. Fortunately, the fire did not cause major damage other than burning dry grass and damaging the rose bushes outside the vineyard. Soil samples were taken from three areas: 1) control (unburned place), 2) a burned place after the heating of grass only - we assumed here a low severity of fire, 3 ) a burned place after heating of grass + shrub roses - we assumed here a higher 
severity of fire due to the burning of higher dry mass content. Soil sampling was performed in spring (May 2010) at a depth of $0-5$ and 5-20 cm. For each zone sampled (including all plots of fire + unburned "control" plot), five different locations were chosen randomly. On each location, soil samples were collected and mixed to form an average sample. Large clods were gently broken up along natural fracture lines, and then air-dried at a laboratory temperature, meaning we achieved undisturbed soil samples for the determination of individual size fractions of aggregates and parameters of soil structure. A part of the soil sample was grinded before analysis - and disturbed soil samples could be used for the determination of SOM parameters.

\section{Laboratory analyses}

The undisturbed soil samples after drying were used for the determination of individual size fractions of water stable aggregates (WSA). Prior to this, all soil samples were sieved to provide a range of aggregate sizes $(>7,7-5,5-3,3-1$, $1-0.5,0.5-0.25,<0.25 \mathrm{~mm}$ ) and these size fractions of air-dried aggregates were used for the determination of size distribution of WSA by the Baksheev method (Vadjunina, Korchagina, 1986). The size fractions of WSA produced were: $>5,5-3,3-2,2-1,1-0.5,0.5-0.25$ as $\mathrm{WSA}_{\mathrm{ma}}$ and $<0.25 \mathrm{~mm}_{\text {as }} \mathrm{WSA}_{\mathrm{mi}}$. In disturbed soil samples, the content of soil organic carbon $\left(\mathrm{C}_{\mathrm{org}}\right)$ was assessed by the wet combustion method (oxidation of organic matter by a mixture of $\mathrm{H}_{2} \mathrm{SO}_{4}$ and $\mathrm{K}_{2} \mathrm{Cr}_{2} \mathrm{O}_{7}$ with titration using Mohr's salt) as is described in Dziadowiec and Gonet (1999). The composition of humus fractions, humic (HA) and fulvic (FA) acids was determined according to Belchikova and Kononova (Dziadowiec, Gonet, 1999). The absorbance of humus substances and humic acids was measured at 465 and $650 \mathrm{~nm}$ to calculate the colour quotient $\mathrm{Q}^{4 / 6} \mathrm{HS}$ and $\mathrm{Q}^{4 / 6}{ }_{\mathrm{HA}}$. The labile carbon content $\left(\mathrm{C}_{\mathrm{L}}\right)$ (Loginow et al., 1987), hot watersoluble carbon $\left(\mathrm{C}_{\mathrm{HWD}}\right)$ and cold water-soluble carbon $\left(\mathrm{C}_{\mathrm{CWD}}\right)$ (Körschens, 2002) were also determined. The same methods used in the soil analysis were used to determine the content of $\mathrm{C}_{\text {org }}$ and $\mathrm{C}_{\mathrm{L}}$ in individual size fractions of WSA. On the bases of the analytical data, the parameters of soil structure were calculated.

The mean weight diameters of aggregates for dry $\left(\mathrm{MWD}_{\mathrm{d}}\right)$ and wet $\left(\mathrm{MWD}_{\mathrm{w}}\right)$ sieving as well as vulnerability coefficient $(\mathrm{Kv})$ were calculated according to following equations (1-3):

$$
\mathrm{MWD}_{\mathrm{d}}=\sum_{i-1}^{n} x i w i
$$

where $M W D_{d}$ is the mean weight diameter of aggregates for dry sieving $(\mathrm{mm}), x i$ is the mean diameter of each size fraction ( $\mathrm{mm})$ and $w i$ is the portion of the total sample weight occurring in the corresponding size fraction, and $n$ is the number of size fractions.

$$
\mathrm{MWD}_{\mathrm{w}}=\sum_{i=1}^{n} x i W S A
$$

where $M W D_{w}$ is the mean weight diameter of WSA $(\mathrm{mm}), x i$ is the mean diameter of each size fraction (mm), WSA is the portion of the total sample weight occurring in the corresponding size fraction and $n$ is the number of size fractions.

$$
\mathrm{Kv}=\frac{M W D_{d}}{M W D_{w}}
$$

where $M W D_{d}$ is the mean weight diameter of aggregates for dry sieving $(\mathrm{mm})$ and $M W D_{w}$ is the mean weight diameter of WSA (mm).

The structure coefficient (K) was calculated according to Equation (4):

$$
\mathrm{K}=\frac{A}{B}
$$


where $A$ is the weight of air-dried aggregates in size fractions from 0.25 to $7 \mathrm{~mm}$ and $B$ is the sum of weight of airdried aggregates in size fraction more than $7 \mathrm{~mm}$ and less than $0.25 \mathrm{~mm}$.

The coefficient of aggregate stability (Ks) was calculated as well according to Equation (5):

$$
\mathrm{Ks}=\frac{A}{B}
$$

where $A$ is the weight of WSA in size fractions from 0.25 to $>5 \mathrm{~mm}$ and $B$ is the weight of WSA less than $0.25 \mathrm{~mm}$.

Statistical analysis

Statistical data analysis was performed using the computer program Statgraphics Centurion XV.I (Statpoint Technologies, Inc., USA). A multifactor ANOVA model was carried out to test whether the SOM and parameters of soil structure varied significantly due to the different severity of fire and depth, with a separation of the means by the LSD multiple-range test at $P \leq 0.05$.

\section{Results and discussion}

\section{Effect of fire on soil structure}

The effect of fire on changes of WSA content was obvious (Table 1). In the plot with a low

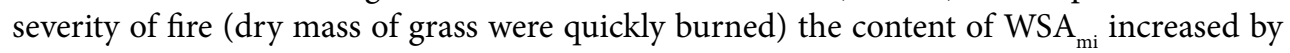
$20 \%$. In the area with the higher severity of fire, where both dry masses of grass and also shrub roses were burned, the content of WSA $_{\mathrm{mi}}$ decreased by $42 \%$ in comparison to original (unburned) soil. The main reason for the results seen with a low severity of fire is in the destruction of macro- to microaggregates in the soils as was observed by Mataix-Solera et al. (2002). Fire can reduce the soil C pools (Soto et al., 1991; Zavala et al., 2010) associated with macroaggregates and therefore can disrupt stabilization mechanisms (Garcia-Oliva et al., 1999). In Rendzic Leptosol, which is the investigated soil type (Šimanský et al., 2013), the aggregation process and soil structure stability is mainly dependent on the SOM. In the case of the higher severity of fire, a significant decrease of WSA ${ }_{\text {mi }}$ can be connected with the thermal fusion of particles and recrystallisation of minerals in the clay fraction (Giovannini, Lucchesi, 1997) leading to the formation of more resistant aggregates. However, we do not expect to see this effect because of the short burning time. Rather, we assume that the reduction of

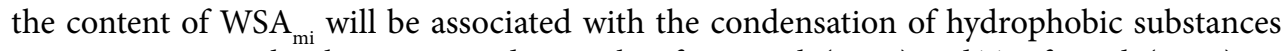
onto aggregates as has been reported in works of Fox et al. (2007) and Terefe et al. (2008). In individual size fractions of WSA ${ }_{\mathrm{ma}}$, mainly in size fractions $>5 \mathrm{~mm}, 5-3 \mathrm{~mm}, 2-1 \mathrm{~mm}, 1-0.5$ and also $0.5-0.25 \mathrm{~mm}$, statistical significant differences were observed. The higher severity of fire resulted in a decrease of smaller size fractions of WSA ma $(0.5-0.25)$ and a low severity of fire resulted in the decrease of WSA ${ }_{\mathrm{ma}} 2-0.5 \mathrm{~mm}$. The results of Andreu et al. (2001) showed the degradation effect of high temperatures on aggregation and a clear reduction in the macroaggregates and increase in the microaggregates, particularly in the $<1 \mathrm{~mm}$ fraction. On the other hand, the content of WSA ma $_{\text {in }}$ size fraction $>5 \mathrm{~mm}$ was higher by $54 \%$ and by $32 \%$ in the low and higher severity of fire, respectively, than in unburned soil. On average, we determined higher contents of WSA $\mathrm{ma}_{\mathrm{ma}}$ in size fractions $>5 \mathrm{~mm}$ and between 5-2 $\mathrm{mm}$ taken from the depth $0-5 \mathrm{~cm}$ compared to the samples taken from the depth 5-20 cm (Table 1). 
T a b l e 1. Statistical evaluation of water-stable aggregates (individual size fractions, contents in \%).

\begin{tabular}{|l|c|c|c|c|c|c|c|c|}
\hline & \multicolumn{7}{|c|}{ Size fractions of water-stable aggregates in mm } \\
\hline & $>5$ & $\mathbf{5 - 3}$ & $\mathbf{3 - 2}$ & $\mathbf{2 - 1}$ & $\mathbf{1 - 0 . 5}$ & $\mathbf{0 . 5}-\mathbf{0 . 2 5}$ & $<\mathbf{0 . 2 5}$ \\
\hline Depth in cm & $13.4^{\mathrm{b}}$ & $13.6^{\mathrm{a}}$ & $14.6^{\mathrm{a}}$ & $15.6^{\mathrm{a}}$ & $15.7^{\mathrm{a}}$ & $12.4^{\mathrm{a}}$ & $14.2^{\mathrm{a}}$ \\
\hline $0-5$ & $8.18^{\mathrm{a}}$ & $11.8^{\mathrm{a}}$ & $13.0^{\mathrm{a}}$ & $16.2^{\mathrm{a}}$ & $17.4^{\mathrm{a}}$ & $18.0^{\mathrm{b}}$ & $15.5^{\mathrm{a}}$ \\
\hline $5-20$ & $8.40^{\mathrm{a}}$ & $10.8^{\mathrm{a}}$ & $12.7^{\mathrm{a}}$ & $16.3^{\mathrm{b}}$ & $18.7^{\mathrm{b}}$ & $16.5^{\mathrm{b}}$ & $16.0^{\mathrm{ab}}$ \\
\hline Fire plots & $12.9^{\mathrm{b}}$ & $12.6^{\mathrm{ab}}$ & $13.0^{\mathrm{a}}$ & $13.3^{\mathrm{a}}$ & $13.2^{\mathrm{a}}$ & $15.8^{\mathrm{ab}}$ & $19.2^{\mathrm{b}}$ \\
\hline Control (unburned) & $11.1^{\mathrm{ab}}$ & $14.8^{\mathrm{b}}$ & $15.6^{\mathrm{a}}$ & $18.2^{\mathrm{c}}$ & $17.8^{\mathrm{b}}$ & $13.4^{\mathrm{a}}$ & $9.27^{\mathrm{a}}$ \\
\hline Low-severity fire &
\end{tabular}

Different letters between lines $(\mathrm{a}, \mathrm{b}, \mathrm{c})$ indicate that treatment means are significantly different at $\mathrm{P} \leq 0.05$ according to LSD multiple-range test.

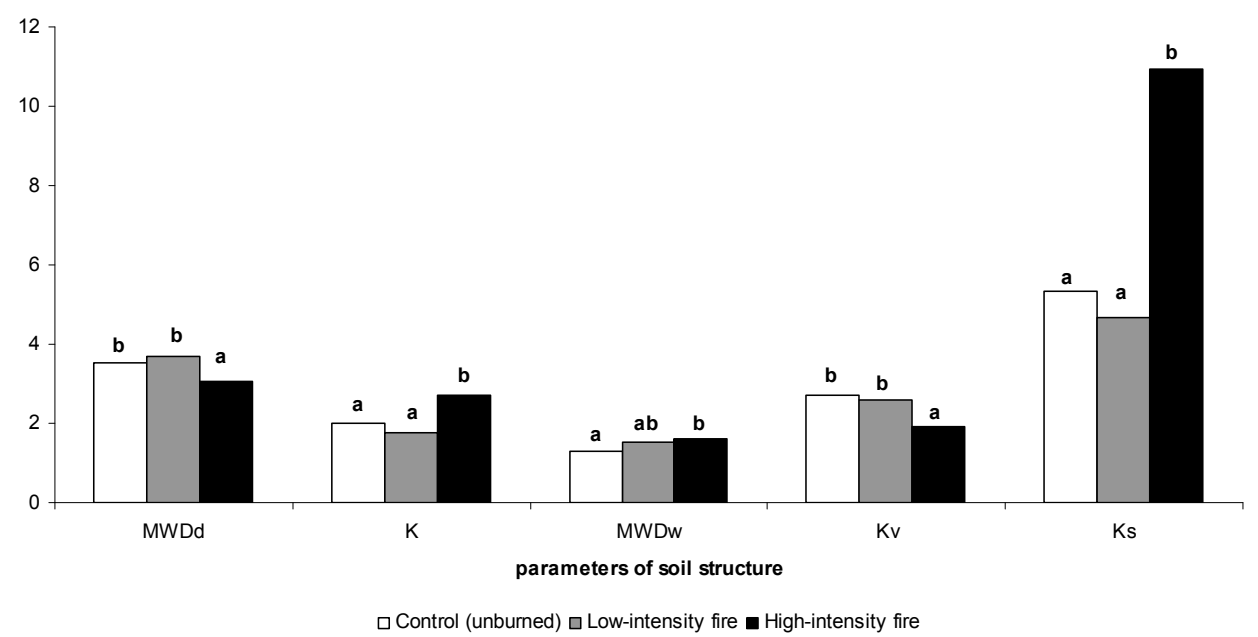

Fig. 1. Parameters of soil structure stability and vulnerability.

Different letters between columns $(\mathrm{a}, \mathrm{b})$ indicate that treatment means are significantly different at $\mathrm{P} \leq 0.05$ according to LSD multiple-range test.

$\mathrm{MWD}_{\mathrm{d}}$ - mean weight diameter of aggregates for dry sieving, $\mathrm{K}$ - structure coefficient, $\mathrm{MWD}_{\mathrm{w}}$ - mean weight diameter of water stable aggregates, $\mathrm{Kv}$ - vulnerability coefficient, $\mathrm{Ks}$ - coefficient of aggregate stability.

The stability of aggregates and their vulnerability to fire can be highly variable confirming the results of previous works (Llovet et al., 2009; Jordán et al., 2011; Šimanský et al., 2012). Parameters of soil structure stability and vulnerability are summarized in Fig. 1. The higher severity of fire had a more positive effect on increases of the structure coefficient and coefficient of aggregate stability, as well as on the decrease of the vulnerability coefficient compared to the low severity of fire. Specifically, the values of structure coefficient and the coefficient of aggregate stability were worse by $17 \%$ and by $13 \%$, respectively, under the low severity of fire compared to the original soil (control). For example, O'Dea (2007) observed a decrease in aggregate stability due to decrease of fungi in soil two years after a fire. Under the higher sever- 
ity of fire, the coefficient of aggregate stability was almost twice as high than in the unburned soil (Fig. 1). Mataix-Solera et al. (2011) reported that the stability of aggregates depends on a lot of factors such as SOM, mineral composition, soil water repellence, fire intensity and severity, time and temperature of burning and many more. For example, in sandy soils under a higher severity of fire, the aggregate stability is decreased while the opposite result is seen in soils with a high clay content. Here calcium carbonate, $\mathrm{Fe}$ and $\mathrm{Al}$ oxides act as principal cementing substances under the higher intensity of fire and so aggregate stability is increased. In our case under the higher severity of fire, the better soil structure has been probably due to an increase of SOM (Table 2).

T a b l e 2. Statistical evaluation of soil organic matter parameters.

\begin{tabular}{|c|c|c|c|c|c|c|c|}
\hline & $\mathrm{C}_{\text {org }}$ & $\mathrm{C}_{\mathrm{L}}$ & $\mathrm{C}_{\mathrm{HWD}}$ & $\mathrm{C}_{\mathrm{CWD}}$ & \multirow[t]{2}{*}{$\mathrm{C}_{\mathrm{HA}}: \mathrm{C}_{\mathrm{FA}}$} & \multirow[t]{2}{*}{$\mathbf{Q}_{\mathrm{HS}}$} & \multirow{2}{*}{$\mathbf{Q}_{\mathrm{HA}}$} \\
\hline & $\mathrm{g} / \mathrm{kg}$ & \multicolumn{3}{|c|}{$\mathrm{mg} / \mathrm{kg}$} & & & \\
\hline \multicolumn{8}{|l|}{ Depth in cm } \\
\hline $0-5$ & $24.7^{\mathrm{b}}$ & $3163^{b}$ & $852^{\mathrm{b}}$ & $249^{\mathrm{a}}$ & $1.06^{\mathrm{a}}$ & $5.97^{\mathrm{a}}$ & $5.46^{\mathrm{a}}$ \\
\hline $5-20$ & $13.2^{\mathrm{a}}$ & $1573^{\mathrm{a}}$ & $587^{\mathrm{a}}$ & $233^{\mathrm{a}}$ & $1.25^{\mathrm{b}}$ & $6.40^{\mathrm{b}}$ & $6.18^{\mathrm{b}}$ \\
\hline \multicolumn{8}{|l|}{ Fire plots } \\
\hline Control (unburned) & $13.7^{\mathrm{a}}$ & $1580^{\mathrm{a}}$ & $622^{\mathrm{a}}$ & $231^{\mathrm{a}}$ & $1.01^{\mathrm{a}}$ & $6.34^{\mathrm{a}}$ & $6.07^{\mathrm{a}}$ \\
\hline Low-severity fire & $2.10^{\mathrm{b}}$ & $2537^{\mathrm{b}}$ & $813^{\mathrm{b}}$ & $259^{\mathrm{a}}$ & $1.15^{\mathrm{b}}$ & $6.23^{\mathrm{a}}$ & $5.69^{\mathrm{a}}$ \\
\hline High-severity fire & $2.23^{\mathrm{b}}$ & $2987^{b}$ & $725^{\mathrm{ab}}$ & $234^{\mathrm{a}}$ & $1.32^{\mathrm{c}}$ & $6.00^{\mathrm{a}}$ & $5.70^{\mathrm{a}}$ \\
\hline
\end{tabular}

Different letters between lines $(\mathrm{a}, \mathrm{b}, \mathrm{c})$ indicate that treatment means are significantly different at $\mathrm{P} \leq 0.05$ according to LSD multiple-range test.

\section{Effect of fire on soil organic matter}

Atanassova et al. (2009) reported an increase of soil organic carbon in top after fire in Lyulin mountain, Bulgaria. This increase was associated with the incorporation of burnt plant residues into the soil (Johnson, Curtis, 2001). The parameters of SOM quantity and quality are shown in Table 2 . The content of $\mathrm{C}_{\text {org }}, \mathrm{C}_{\mathrm{L}}$ and $\mathrm{C}_{\mathrm{HWD}}$ was significantly high in the layer $0-5 \mathrm{~cm}$ than $5-20 \mathrm{~cm}$. After burning, the contents of $\mathrm{C}_{\text {org }}$ and $\mathrm{C}_{\mathrm{L}}$ were significantly increased by the severity of fire. However, as reported by Mataix-Solera et al. (2002) it is not unusual to find an increase in SOM after moderate severity wildfires. On the other hand in our results, the low severity of fire affected more markedly the increase of $\mathrm{C}_{\mathrm{HWD}}$ and $\mathrm{C}_{\mathrm{CWD}}$ than the higher severity of fire. These results show that there is a clear connection with the burning temperature. Probably since the temperature was lower, the SOM was not totally burned. Fire, except SOM quantity affects its quality (Garcia-Oliva et al., 1999). At the surface layer $(0-5 \mathrm{~cm})$, the quality of SOM was worst, but SOM stability was better in comparison to the second layer $(5-20 \mathrm{~cm})$. The control soil had significantly the lowest value of $\mathrm{C}_{\mathrm{HA}}: \mathrm{C}_{\mathrm{FA}}$ (worst quality) and higher (no significant) values of $\mathrm{Q}_{\mathrm{HS}}$ and $\mathrm{Q}_{\mathrm{HA}}$ than the soil after fire. After burning and due to the severity of fire, both the ratios of $\mathrm{C}_{\mathrm{HA}}: \mathrm{C}_{\mathrm{FA}}$ and SOM stability (lower values = better stability) increased. In summary, in the case of higher severity fires, the pyromorphic humus formed shows an increased stability to chemical and biological degradation. 
Soil organic matter plays an important role in the formation of aggregates in many soils (Oades, 1993; Roldán et al., 1994; Šimanský, Bajčan, 2014) and therefore we also determined its contents in WSA (Table 3). The content of SOM due to fire significantly increased also

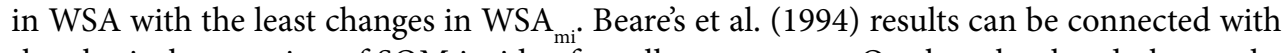
the physical protection of SOM inside of smaller aggregates. On the other hand, the results of Šimanský et al. (2012) showed that the content of total carbon in WSA was almost threefold in $\mathrm{WSA}_{\mathrm{mi}}$ than in WSA ${ }_{\mathrm{ma}}$ in soil affected by fire. As it was mentioned above, it can be connected with the severity of fire. The results showed that a low severity of fire increased $\mathrm{C}_{\text {org }}$ mainly in $\mathrm{WSA}_{\mathrm{ma}}>2 \mathrm{~mm}$ and $\mathrm{WSA}_{\mathrm{mi}}$. On the other hand, high severity fire increased $\mathrm{C}_{\text {org }}$ content in a smaller fraction of WSA ${ }_{\mathrm{ma}}$. A similar trend was observed in contents of $\mathrm{C}_{\mathrm{L}}$ in WSA. For example, Terefe et al. (2008) found that low severity fires had no effect on soil organic carbon, however, organic $\mathrm{C}$ was totally eliminated when soil was heated at $400{ }^{\circ} \mathrm{C}$ (Fernández et al., 1997).

$\mathrm{T} \mathrm{a} \mathrm{b} \mathrm{le} \mathrm{3.} \mathrm{Statistical} \mathrm{evaluation} \mathrm{of} \mathrm{soil} \mathrm{organic} \mathrm{matter} \mathrm{parameters} \mathrm{in} \mathrm{individual} \mathrm{size} \mathrm{fraction} \mathrm{of} \mathrm{water-stable} \mathrm{aggregates.}$

\begin{tabular}{|c|c|c|c|c|c|c|c|}
\hline \multicolumn{8}{|c|}{ Soil organic carbon $(\mathrm{g} / \mathrm{kg})$} \\
\hline & \multicolumn{7}{|c|}{ Size fractions of water-stable aggregates in $\mathbf{~ m m}$} \\
\hline & $>5$ & $5-3$ & $3-2$ & $2-1$ & $1-0.5$ & $0.5-0.25$ & $<0.25$ \\
\hline \multicolumn{8}{|l|}{ Depth in cm } \\
\hline $0-5$ & $27.0^{\mathrm{b}}$ & $23.0^{\mathrm{b}}$ & $21.8^{\mathrm{b}}$ & $25.1^{\mathrm{b}}$ & $26.6^{\mathrm{b}}$ & $19.2^{\mathrm{b}}$ & $8.10^{\mathrm{b}}$ \\
\hline $5-20$ & $17.0^{\mathrm{a}}$ & $14.2^{\mathrm{a}}$ & $13.6^{\mathrm{a}}$ & $13.1^{\mathrm{a}}$ & $10.3^{\mathrm{a}}$ & $7.90^{\mathrm{a}}$ & $7.30^{\mathrm{a}}$ \\
\hline \multicolumn{8}{|l|}{ Fire plots } \\
\hline Control (unburned) & $13.3^{\mathrm{a}}$ & $13.4^{\mathrm{a}}$ & $13.9^{\mathrm{a}}$ & $14.5^{\mathrm{a}}$ & $11.3^{\mathrm{a}}$ & $7.50^{\mathrm{a}}$ & $7.20^{\mathrm{a}}$ \\
\hline Low-severity fire & $28.3^{\mathrm{b}}$ & $23.3^{\mathrm{b}}$ & $21.4^{\mathrm{b}}$ & $21.2^{\mathrm{a}}$ & $25.6^{\mathrm{b}}$ & $16.4^{\mathrm{b}}$ & $8.50^{\mathrm{b}}$ \\
\hline High- severity fire & $24.3^{\mathrm{b}}$ & $19.1^{\mathrm{ab}}$ & $17.8^{\mathrm{ab}}$ & $21.7^{\mathrm{a}}$ & $18.5^{\mathrm{ab}}$ & $16.9^{\mathrm{b}}$ & $7.50^{\mathrm{a}}$ \\
\hline \multicolumn{8}{|c|}{ Labile carbon (mg/kg) } \\
\hline \multicolumn{8}{|l|}{ Depth in cm } \\
\hline $0-5$ & $5054^{\mathrm{b}}$ & $3611^{\mathrm{b}}$ & $2738^{\mathrm{b}}$ & $3311^{\mathrm{b}}$ & $4046^{\mathrm{b}}$ & $2911^{\mathrm{b}}$ & $1118^{\mathrm{b}}$ \\
\hline $5-20$ & $3177^{\mathrm{a}}$ & $2457^{\mathrm{a}}$ & $1657^{\mathrm{a}}$ & $1988^{\mathrm{a}}$ & $1965^{\mathrm{a}}$ & $1145^{\mathrm{a}}$ & $981^{\mathrm{a}}$ \\
\hline \multicolumn{8}{|l|}{ Fire plots } \\
\hline Control (unburned) & $2546^{\mathrm{a}}$ & $2021^{\mathrm{a}}$ & $1383^{\mathrm{a}}$ & $1682^{\mathrm{a}}$ & $1582^{\mathrm{a}}$ & $1029^{a}$ & $1003^{\mathrm{a}}$ \\
\hline Low- severity fire & $5800^{c}$ & $3557^{\mathrm{b}}$ & $2647^{\mathrm{b}}$ & $2586^{\mathrm{ab}}$ & $4260^{\mathrm{b}}$ & $2664^{\mathrm{b}}$ & $1138^{\mathrm{b}}$ \\
\hline High- severity fire & $4001^{\mathrm{b}}$ & $3526^{\mathrm{b}}$ & $2563^{\mathrm{b}}$ & $3681^{\mathrm{b}}$ & $3175^{\mathrm{ab}}$ & $2392^{\mathrm{b}}$ & $1008^{\mathrm{a}}$ \\
\hline
\end{tabular}

Different letters between lines $(\mathrm{a}, \mathrm{b}, \mathrm{c})$ indicate that treatment means are significantly different at $\mathrm{P} \leq 0.05$ according to LSD multiple-range test.

\section{Conclusion}

The results of this study showed that after the fire both the quantity and quality of SOM can be changed and the soil structure improves. Increasing of SOM quantity and quality depends on the severity of the fire and this effect is connected with a higher aggregate stability and the formation of a favourable structural state of soil. Obtained results confirmed that SOM plays an important role in the formation of aggregates after fire. The results broaden knowl- 
edge and demonstrate the behavioural changes in the concrete soil type and its ability to deal with fire. Fire-induced changes on SOM and soil structure data could be used for predicting changes after fire in the mentioned soil type (Rendzic Leptosols). Future studies with other soil types and fire severities are required.

\section{Acknowledgements}

Author thanks Matthew Evans (Brackley, England) for improving the English text and also the editor and reviewers, for constructive comments.

\section{References}

Aelamanesh, P., Mosaddeghi, M.R., Mahboubi, A.A., Ahrens, B. \& Safari Sinegani A.A. (2014). Water repellency in calcareous soils under different land uses in Western Iran. Pedosphere, 24(3), 378-390. DOI: 10.1016/S10020160(14)60024-2.

Albalasmeh, A.A., Berli, M., Shafer, D., Teamrat, S. \& Ghezzehe A. (2013). Degradation of moist soil aggregates by rapid temperature rise under low intensity fire. Plant Soil, 362, 335-344. DOI: 10.1007/s11104-012-1408-z.

Andreu, V., Imeson, A. \& Rubio J.L. (2001). Temporal changes in soil macro and microaggregation induced by forest fires and its incidence on water erosion. Catena, 44(1), 69-84. DOI: 10.1016/S0341-8162(00)00177-6.

Arcenegui, V., Mataix-Solera, J., Guerrero, C., Zornoza, R., Mataix-Beneyto, J. \& García-Orenes F. (2008). Immediate effects of wildfires on water repellency and aggregate stability in Mediterranean calcareous soils. Catena, 74(3), 219-226. DOI: 10.1016/j.catena.2007.12.008.

Atanassova, I., Teoharov, M. \& Ivanov P. (2009). Characterisation of a fire affected catena sequence from Lyulin Mountain Bulgaria. Bulgarian Journal of Agricultural Science, 15, 333-340.

Beare, M.H., Cabrera, M.L., Hendrix, P.F. \& Coleman D.C. (1994). Aggregate-protected and unprotected organic matter pools in conventional and no-tillage soils. Soil Sci. Soc. Am. J., 58, 787-795. DOI: 10.2136/sssaj1994.03 $615995005800030021 x$.

Dziadowiec, H. \& Gonet S.S. (1999). Methodical guide-book for soil organic matter studies (in Polish). Warszawa: Prace komisji naukowych Polskiego towarystwa gleboznaczego.

Fernández, I., Cabaneiro, A. \& Carballas T. (1997). Organic matter changes immediately after a wildfire in an Atlantic forest soil and comparison with laboratory soil heating. Soil Biol. Biochem., 29, 1-11. DOI: 10.1016/ S0038-0717(96)00289-1.

Fox, D.M., Darboux, F. \& Carrega P. (2007). Effects of fire-induced water repellency on aggregate stability, splash erosion, and saturated hydraulic conductivity for different size fractions. Hydrological Processes, 21, 2377-2384. DOI: $10.1002 /$ hyp.6758.

García-Corona, R., Benito, E., de Blas, E. \& Varela M.E. (2004). Effects of heating on some soil physical properties related to its hydrological behaviour in two north-western Spanish soils. Int. J. Wildland Fire, 13, 195-199. DOI: 10.1071/WF03068.

García-Oliva, F., Sandford, Jr. R.L. \& Kelly E. (1999). Effects of slash-and-burn management on soil aggregate organic $\mathrm{C}$ and $\mathrm{N}$ in a tropical deciduous forest. Geoderma, 88, 1-12. DOI: 10.1016/S0016-7061(98)00063-9.

Giovannini, G. \& Lucchesi S. (1997). Modifications induced in soil physico-chemical parameters by experimental fires at different intensities. Soil Sci., 162, 479-486.

Hötzl, H. (2008). Water resources management in the Middle East under aspects of climatic changes. Berlin, Heidelberg: Springer.

Johnson, D.W. \& Curtis P.S. (2001). Effects of forest management on soil C and N storage: meta analysis. For. Ecol. Manag., 140, 227-238. DOI: 10.1016/S0378-1127(00)00282-6.

Jordán, A., Zavala, L.M., Mataix-Solera, J., Nava, A.L. \& Alanís N. (2011). Effect of fire severity on water repellency and aggregate stability on Mexican volcanic soils. Catena, 84(3), 136-147. DOI: 10.1016/j.catena.2010.10.007.

Körschens, M. (2002) Importance of soil organic matter (SOM) for biomass production and environment a review. Archiv für Acker- und Pflanzenbau und Bodenkunde, 48, 89-94. DOI: 10.1080/03650340214162.

Llovet, J., Ruiz-Valera, M., Josa, R. \& Vallejo V.R. (2009). Soil responses to fire in Mediterranean forest landscapes in relation to the previous stage of land abandonment. Int. J. Wildland Fire, 18, 222-232. DOI: 10.1071/WF07089.

Loginow, W., Wisniewski, W., Gonet, S.S. \& Ciescinska B. (1987). Fractionation of organic carbon based on suscep- 
tibility to oxidation. Polish Journal of Soil Science, 20, 47-52.

Mataix-Solera, J., Gómez, I., Navarro-Pedreño, J., Guerrero, C. \& Moral R. (2002). Soil organic matter and aggregates affected by wildfire in a Pinus halepensis forest in Mediterranean environment. Int. J. Wildland Fire, 11, 107-114. DOI: 10.1071/WF02020.

Mataix-Solera, J., Cerdà, A., Arcenegui, V., Jordán, A. \& Zavala L.M. (2011). Fire effects on soil aggregation: A review. Earth-Science Reviews, 109, 44-60. DOI: 10.1016/j.earscirev.2011.08.002.

Oades, J.M. (1993). The role of biology in the formation, stabilization and degradation of soil structure. Geoderma, 56, 377-400. DOI: 10.1016/0016-7061(93)90037-L.

O'Dea, M.E. (2007). Fungal mitigation of soil erosion following burning in a semi-arid Arizona savanna. Geoderma, 138(1-2), 79-85. DOI: 10.1016/j.geoderma.2006.10.017.

Roldán, A., García-Orenes, F. \& Lax A. (1994). An incubation experiment to determinate factors involving aggregation changes in an arid soil receiving urban refuse. Soil Biol. Biochem., 26, 1699-1707. DOI: 10.1016/00380717(94)90323-9.

Soto, B., Benito, E. \& Díaz-Fierros F. (1991). Heat-induced degradation processes in forest soils. Int. J. Wildland Fire, 1(3), 147-152. DOI: 10.1071/WF9910147.

Šimanský, V., Chlpík, J. \& Gonet S.S. (2012). Soil organic matter and aggregates stability in soils after windstorm and fire damage in the High Tatras Mountains. Ekológia (Bratislava), 31(3), 322-330. DOI: 10.4149/ ekol_2012_03_322.

Šimanský, V. (2013). Soil organic matter in water-stable aggregates under different soil management practices in a productive vineyard. Archives of Agronomy and SoilScience, 59(9), 1207-1214. DOI: 10.1080/03650340.2012.708103.

Šimanský, V., Bajčan, D. \& Ducsay L. (2013). The effect of organic matter on aggregation under different soil management practices in a vineyard in an extremely humid year. Catena, 101, 108-113. DOI: 10.1016/j.catena.2012.10.011.

Šimanský, V. \& Bajčan D. (2014). The stability of soil aggregates and their ability of carbon sequestration. Soil and Water Research, 9(3), 111-118.

Terefe, T., Mariscal-Sancho, I., Peregrina, F. \& Espejo R. (2008). Influence of heating on various properties of six Mediterranean soils. A laboratory study. Geoderma, 143(3-4), 273-280. DOI: 10.1016/j.geoderma.2007.11.018.

Urbanek, E. (2013). Why are aggregates destroyed in low intensity fire? Plant Soil, 362, 33-36. DOI: 10.1007/s11104012-1470-6.

Vadjunina, A.F. \& Korchagina Z.A. (1986). Methods of study of soil physical properties (in Russian). Moscow: Agropromizdat.

WRB (2006). World reference base for soil resources 2006, World Soil Resources Reports No. 103. Rome: FAO.

Zavala, L.M., Granged, A.P., Jordán, A. \& Bárcenas-Moreno G. (2010). Effect of burning temperature on water repellency and aggregate stability in forest soils under laboratory conditions. Geoderma, 158(3-4), 366-374. DOI: 10.1016/j.geoderma.2010.06.004. 